Pace University

DigitalCommons@Pace

$1-1-1980$

\title{
Harmless Error: Constitutional Sneak Thief
}

Steven H. Goldberg

Elisabeth Haub School of Law at Pace University

Follow this and additional works at: https://digitalcommons.pace.edu/lawfaculty

Part of the Constitutional Law Commons, and the Criminal Law Commons

\section{Recommended Citation}

Steven H. Goldberg, Harmless Error: Constitutional Sneak Thief, 71 J. Crim. L. \& Criminology 421 (1980), http://digitalcommons.pace.edu/lawfaculty/84/.

This Article is brought to you for free and open access by the School of Law at DigitalCommons@Pace. It has been accepted for inclusion in Pace Law Faculty Publications by an authorized administrator of DigitalCommons@Pace. For more information, please contact dheller2@law.pace.edu. 


\section{HARMLESS ERROR: CONSTITUTIONAL SNEAK THIEF}

\section{STEVEN H. GOLDBERG*}

1
"Harmless constitutional error" is among the most insidious of legal doctrines. Since its promulgation by the United States Supreme Court in Chapman v. Califormia, ${ }^{1}$ it has determined as many criminal appeals as have some of the more wellknown and hotly debated decisions of the 1960s. ${ }^{2}$ Despite the frequency of its use in determining criminal appeals-possibly as high as ten percent of all criminal appeals during the last thirteen years ${ }^{3}$-it has received comparatively little critical

* Assistant Professor, University of Arkansas at Little Rock School of Law; J.D., University of Minnesota, 1968; B.A., Northwestern University, 1963.

1386 U.S. 18 (1967).

${ }^{2}$ It is probably impossible to determine exactly how many cases have been "determined" by a prior precedent. Shepard's United States Citations lists in excess of 6000 citations to Chapman v. Califormia. While some of those citations probably represent cases which found the error "harmful," Chapman is almost always cited as authority for an appellate court's finding of "harmlessness." A rough comparison with the page measure of the citations to Mapp v. Ohio, 367 U.S. 643 (1961), and Miranda v. Arizona, 384 U.S. 436 (1966), two of the major decisions of the Warren Court, supports the proposition that Chapman has determined as many cases as almost any precedent from the decade. While both Miranda and Mapp are cited more often, they are more often distinguished or explained and frequently appear numerous times in the same case.

${ }^{3}$ The empirical research to establish the exact relationship between harmless constitutional error determinations and all criminal appeals is probably not worth the effort. The available data and a couple of assumptions make a fair argument for the likelihood of the 10 percent estimate. While the Shepard's citations undoubtedly include some cases of harmful error and some multiple citations in the same case, a number of cases are determined by a finding of harmless constitutional error without any mention of Chapman. Harrington v. California, 395 U.S. 250 (1969), provided a less rigorous test than Chapman and is often cited in preference to Chapman. Similarly, many state courts cite the state authority for harmless constitutional error rather than Chapman. It is not unreasonable to assume that the cases which do not cite Chapman for the harmless error proposition are at least as numerous as those that do and do not find the error harmless. Something in excess of two-thirds of the Shepard's citations to Chapman are in state cases.

The available data for harmless error as a percentage of appellate decisions is found in Note, Harmful Use of Harmless Error in Criminal Cases, 64 CoRnell L. Rev. 538 (1979) (hereinafter Harmful Use). The Note presents a comparison of all federal cases mentioning harmless error to all cases in the federal circuits from 1960 through 1978. attention. ${ }^{4}$ The reason for the inattention? It's a sneak thief. Its appearance does not raise apprehension, and its application does not leave concentrated areas of obvious constitutional damage. The doctrine does not aim at any closely guarded right. It poses no consistent doctrinal challenge to important judicial determinations; nor does it consistently affect any police practice. Further, it looks like the helpful, familiar doctrine of harmless error. The purpose of this article is to demonstrate that

The data do not discriminate between harmless error and harmless constitutional error. The markedly increased percentage, and the even more dramatic increase in absolute number of harmless error cases following the Chapman opinion, when combined with the observation that there is a rough approximation between the number of federal harmless error cases presented in Harmful Use, supra, and the federal citations in Shepard's for the same period, lead to the conclusion that the number of harmless error cases which are not harmless constitutional error is statistically insignificant.

During the last decade, civil cases outnumbered criminal cases in the federal circuits approximately four-toone. See Department of Commerce, Statistical ABSTRACT OF THE UNrTed States (1979). In Harmful Use, supra, the author estimates that 2.5 percent of all appellate cases in the federal system are harmless error cases. If the civil-to-criminal ratio in the states is comparable to that of the federal system, then approximately 10 percent of all criminal appellate cases throughout the country are determined by a finding of harmless constitutional error. Granting that the figure represents the roughest of approximations, the harmless constitutional error doctrine is apparently a significant factor, at least by volume, in criminal appellate decisionmaking.

${ }^{4}$ When compared to the other major decisions of the 1960s, the harmless error case was ignored. The most complete discussion of harmless error is R. TRAYNOR, THE RidDle of Harmiess ERror (1970). Field, Assessing the Harmlessness of Federal Constitutional Error-A Process in Need of a Rationale, 125 U. PA. L. REv. 15 (1977); Mause, Harmless Constitutional Error: The Implications of Chapman v. Califormia, 53 MrNN. L. REv. 519 (1969); and Saltzburg, The Harm of Harmless Error, 59 VA. L. Rev. 988 (1973), each deal with a particular aspect of the harmless constitutional error problem. A handful of student notes and comments, the most complete of which is Note, Harmless Constitutional Error, 20 Stan. L. Rev. 83 (1967), commented on the Chapman decision. While many of the commentators presented a case for excluding one kind of error or another from the reach of the harmless constitutional error doctrine, none criticized the doctrine as being simply wrong. 
the doctrine of harmless constitutional error destroys important constitutional and institutional values and therefore should be discarded.

\section{Harmless ERror/Harmless Constitutional ERROR}

The lack of apparent concern for the doctrine of harmless constitutional error is attributable, at least in part, to the assumption that harmless constitutional error is simply another variety of harmless error. In fashioning a "harmless-constitutionalerror rule" for the seven-member Chapman majority, Justice Hugo Black made a special attempt to tie his new rule to the harmless error statutes extant in the various jurisdictions: "All 50 States have harmless-error statutes or rules, and the United States long ago through its Congress established for its courts the rule that judgments shall not be reversed for 'errors or defects which do not affect the substantial rights of the parties." "6

Harmless constitutional error is different from harmless error generally, and that difference begins with the statutes and rules in the fifty states. The various harmless error statutes state, in one fashion or another, that a trial result shall not be reversed on appeal unless the trial included a "substantial wrong or miscarriage." The language and the concept originated in England. The method and reason for its eventual transplantation to the United States bears upon whether harmless error is a persuasive precedent for the harmless constitutional error doctrine.

Commentators generally believe the 1835 case of Crease v. Barrett ${ }^{8}$ created the Exchequer Rule which states that prejudice presumptively attends every trial error. ${ }^{9}$ The rule resulted in such overcrowding in the English courts that litigation seemed to survive until the parties expired. Faced with more retrials than new trials, the English created a harmless error rule for civil litigation which prohibited reversal absent substantial wrong.

The American courts adopted the Exchequer

\footnotetext{
${ }^{5} 386$ U.S. at 22 . The phrase is Justice Black's own description of what Justice Stewart considered to be a "break with settled precedent." Id. at 22 (quoting id. at 45 (Powell, J., dissenting) ).

${ }^{6} I d$. at 22 (quoting 28 U.S.C. 2111 (1966)).

${ }^{7}$ See 36 \& 37 Vict., c. 66, rule 6, sched. 1. (1873).

81 C.M. \& R. 919, 149 Eng. Rep. 1353 (Ex. 1835).

${ }^{9}$ Wigmore first blamed Crease for the rule, and most commentators have accepted that genealogy. R. TRAYNOR, supra note 4 , at 4 , argues persuasively that the Exchequer Rule was not invented by Baron Parke in Crease, but rather by the judges who misread the precedent in applying Crease to the case of the moment.
}

Rule and developed the same backlog and delay that plagued the English. Unlike the English, however, the American courts did not change the rule and even in the early twentieth century were still leaving no error unremedied, no matter how inconsequential. Commentators labeled the courts "impregnable citadels of technicality," 10 and by all accounts the label was warranted. Cases were often tried more than once-and once, five times. ${ }^{11}$ Convictions were overturned for matters as inconsequential as the omission of the word "the" before the words "peace and dignity" in an indictment. ${ }^{12}$ One particularly glaring example of delay involved a widow who, twenty-three years after filing suit for the proceeds of her husband's life insurance, appeared before the Supreme Court for the second time. ${ }^{13}$ Many lawyers placed error in the record as a hedge against losing the verdict. ${ }^{14}$ The situation in the courts became intolerable to many members of the organized bar, some judges, and a number of legal scholars. They formed a loose coalition to press for remedial legislation. ${ }^{15}$ The reform movement resulted in "harmless error" legislation in virtually every jurisdiction. ${ }^{16}$ In the words of Justice

${ }^{10}$ Kavanaugh, Improvement of Administration of Criminal Justice by Exercise of Judicial Power, 11 A.B.A.J. 217, 222 (1925).

${ }^{11}$ Pressley v. Bloomington and Normal Ry. \& Light Co., 271 Ill. 622, i11 N.E. 511 (1916), was retried four times without a substantial error.

${ }^{12}$ State v. Campbell, 210 Mo. 202, 109 S.W. 706 (1908).

${ }^{13}$ Connecticut Mutual Life Ins. v. Hillmon, 145 U.S. 285 (1892), 188 U.S. 208 (1903), might have become a national tragedy had the "widow" not been very youngand thereby likely to outlive the lawsuit to spend her winnings-and had there been no suspicion that her husband was not really a "corpse" and she, therefore, not really a "widow."

${ }^{14}$ There was considerable pressure to create a federal harmless error statute with application to civil cases only. See S. Rep. No. 1066, 62nd Cong., 2d Sess. (1911-12). Criminal cases were nonetheless included because, according to Justice Rutledge in Kotteakos v. United States, 328 U.S. 750, 759 (1946), the "criminal trial became a game for sowing reversible error in the record, only to have repeated the same matching of wits when a new trial had been thus obtained."

15 The organized bar spearheaded the coalition, aided by its powerful, if not succinctly named, Special Committee to Suggest Remedies and Formulate Proposed Laws to Prevent Delay and Unnecessary Cost in Litigation. Pound, Taft, Wigmore, Hadley, and Frankfurter were only some of the legal community leaders involved in the coalition.

${ }^{16}$ Some of the harmless error rules, for instance the California constitutional harmless error rule, antedated the reform movement. Most of the statutes and rules, however, were passed during the quarter century in which the coalition was actively involved in lobbying. 
Frankfurter the purpose and limits of the harmless error legislation were: "to prevent matters concerned with the mere etiquette of trials and with the formalities and minutiae of procedure from touching the merits of a verdict."17

With this background, the issue of harmless constitutional error came to the Supreme Court in 1963. Until Fahy v. Connecticut, ${ }^{18}$ no court had suggested that a federal constitutional error might be harmless. The Court had never given any serious consideration to the question, and no constitutional error had gone unremedied by reversal. ${ }^{19}$ Fahy came to the Court in the backwash of Mapp $v$. $O$ Oio $^{20}$ as the states were beginning to struggle with the proposition that the fourth amendment limitations upon search and seizure, and the exclusionary rule remedy for violation of those limitations, were fully applicable to the states. The state charged Fahy and a friend with painting swastikas on a synagogue in violation of its law against willful injury to public buildings. At Fahy's trial, the state introduced the paint and brush used for the artwork. On appeal, the Connecticut court held that the search for and seizure of the paint and brush from the Fahy garage violated the fourth amendment and that Mapp required their exclusion from evidence. ${ }^{21}$ The court refused, however, to reverse the conviction, holding that the error in the admission of the paint and brush had not "materially injured the appellant" under Connecticut's harmless error rule. ${ }^{22}$

The Supreme Court might have pursued several alternatives in Fahy. It could have decided that federal constitutional error never could be harm-

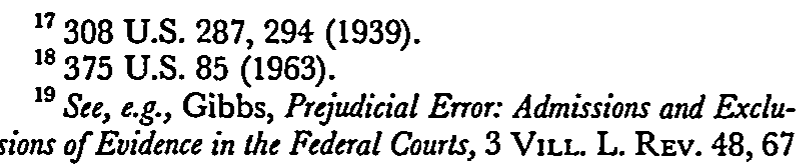
sions of Evidence in the Federal Courts, 3 ViLL. L. REV. 48, 67 v. United States, 178 U.S. 458 (1900), in response to Justice Stewart's claim that constitutional error had always led to reversal. 386 U.S. at 50. Saltzburg, supra note 4 , at 1001 , suggests that Motes may not have been viewed as anything more than a waiver of constitutional rights through Motes' admission of guilt, which amounted to a guilty plea. Regardless of Motes' "true" meaning, the matter of harmless constitutional error was never raised or argued in the Supreme Court before Fahy. Justice Rutledge, in Kotteakos v. United States, 328 U.S. at 76465 , said in dictum that only constitutional norms and specific commands of Congress could insulate error from the federal harmless error statute.

20367 U.S. 643 (1961).

${ }^{21}$ Connecticut v. Fahy, 149 Conn. $577,586,183$ A.2d 256, 261 (1962).

${ }^{22}$ Id. at 588, 183 A.2d at 262; Conn. Gen. Stat. $§ 52-$ 265 (1958). less. It could have decided that courts should judge federal constitutional error by a federal standard of harmlessness. It might have separated the exclusionary rule from the fourth amendment and determined that the admission of the evidence was not constitutional error. The Court chose none of these alternatives. Instead the Court held that Fahy was entitled to a new trial because the Connecticut court wrongly believed that the admission of the evidence would not prejudice Fahy. ${ }^{23}$ Chief Justice Warren, writing for the majority, failed to clarify the basis of the Court's power to instruct a state on the interpretation of its own laws. ${ }^{24}$ More importantly, the opinion is not clear on whether Connecticut read its facts right and its test wrong or its test right and its facts wrong. ${ }^{25}$ The single clear proposition to be gleaned from Fahy is that, had the Connecticut court done its job correctly, it might have found the federal constitutional error to be harmless.

Chapman v. Califormia, ${ }^{26}$ the "harmless error" case, came four years after Fahy. Significantly, Chapman did not involve a fourth amendment violation. Justices Stewart and White, who had joined Justice Harlan's dissent in Fahy, did not join him in Chapman. Insofar as Justice Harlan's position was not significantly different on the relationship between harmless error and constitutional error, it is fair to conclude that the fourth amendment exclusionary rule presents special problems for harmless error. ${ }^{27}$

23 "From the foregoing it clearly appears that the erroneous admission of this illegally obtained evidence was prejudicial to petitioner and hence it cannot be called harmless error." 375 U.S. at 91-92.

${ }^{24}$ Justice Harlan in dissent questioned the Court's power to instruct Connecticut upon the proper interpretation of its own harmless error statute. "Evidentiary questions of this sort are not a proper part of this Court's business, particularly in cases coming here from state courts over which this Court possesses no supervisory power." Fahy v. Connecticut, 375 U.S. at 92 (Harlan, J., dissenting).

${ }^{25}$ The majority opinion goes out of its way to discuss the facts. However, as the dissent points out, reinterpreting the facts is not the task of the United States Supreme Court. Although Connecticut's statute is potentially as rigorous for harmless error as any test the Court might promulgate, the opinion states a harmless error test different from that which Connecticut applied under its own statute. The test which Warren stated in framing the "factual" issue placed the burden on the state to show no "reasonable possibility" that the error contributed to the verdict. It is unlikely that Connecticut read its harmless error test similarly.

${ }^{26} 386$ U.S. 18 (1967).

27 The exclusionary rule presents special problems in a number of contexts. A familiar contention is that most of the procedural cases, see, e.g., Linkletter v. Walker, 381 
Chapman involved California's constitutional rule which allowed the prosecutor to argue to the jury the defendant's failure to testify. ${ }^{28}$ Chapman and a codefendant were charged with a number of crimes, including murder. They chose not to testify at their trial, and the prosecutor made a vigorous argument based upon their failure to explain and contradict the state's evidence. After their trial, but before their appeal, the United States Supreme Court decided Griffin v. California. ${ }^{29}$ In Griffin, the Court held that the California comment rule unconstitutionally eroded the fifth amendment privilege against self-incrimination by making its assertion costly. The California Supreme Court recognized the applicability of Griffin to Chapman's case, but held that under California's test for harmless error the comment to the jury was harmless. ${ }^{30}$

The Chapman opinion is, in its own fashion, as strange as Fahy. Justice Harlan, who did not understand the source of the Fahy Court's power to instruct Connecticut on its own law, had similar difficulty with the source of the Chapman Court's power to create a federal harmless error standard, particularly, given Justice Black's observation that Congress might impose a different standard. ${ }^{31} \mathrm{He}$ concluded that the majority, in a "startling constitutional development" had assumed "a general supervisory power over the trial of federal constitutional issues in state courts." 32 Former Chief Justice Traynor of the California Supreme Court read Justice Black's opinion quite differently, concluding that the Chapman rule was not constitution-

U.S. 618 (1965), and Stone v. Powell, 428 U.S. 465 (1976), represent reactions to the exclusionary principle rather than antipathy to the right involved. Chapman, although not an exclusionary rule case, was decided with the exclusionary rule in the very near background. Further, the exclusionary rule significantly affected the decision to the extent that it tempered Stewart's otherwise uncompromising position that constitutional error was different as a class for purposes of harmless error.

${ }^{28}$ CAL. Const. art. I, $\S 13$.

${ }^{29} 380$ U.S. 609 (1965).

${ }^{30}$ People v. Teale, 63 Cal. 2d 178, 404 P.2d 209, 45 Cal. Rptr. 729 (1965).

${ }^{31} 386$ U.S. at 45 (Harlan, J., dissenting). The limits of federal power-and certainly court power-is the central theme of Justice Harlan's dissent. He makes the argument more completely than he did in Fahy. His dissent, and the failure of Justices Stewart and White to join it, is the best argument for two propositions: (1) the exclusionary rule alone accounted for the Court's avoidance of the harmless error issue in Fahy, and (2) the Chapman determination that federal constitutional error requires a different and more rigorous harmless error test is a "constitutional judgment."

${ }^{32}$ Id. at 45,46 . ally based but rather was an interpretation of the federal harmless error statute. ${ }^{33}$

Much of the difficulty with Chapman is the result of its posture in the Supreme Court, the positions of the parties, and the Court's response to those positions. ${ }^{34}$ The California Supreme Court apparently had concluded that the evidence of guilt presented to the jury was so "overwhelming" that the error was harmless. ${ }^{35}$ The state contended that its harmless error rule represented the proper test. The defendant contended that no constitutional error could ever be harmless. ${ }^{36}$ The majority opinion rejected both contentions and fáshioned a federal harmless error standard. In so doing, Justice Black held that federal constitutional error was sufficiently different from common error to require a different standard, ${ }^{37}$ but not sufficiently different to prohibit any standard at all. ${ }^{38}$ For the latter

${ }^{33} \mathrm{R}$. TRAYNOR, supra note 4 , at $38-42$.

${ }^{34}$ In the most technical sense, the language in Chapman concerning the nature of the harmless constitutional error may be considered dictum. Chapman is the authority used by many appellate courts to find harmless constitutional error, but Chapman did not find such an error. The California court found the error to be harmless; the United States Supreme Court found only that California's use of its own test for harmlessness was wrong.

${ }^{35}$ Whether Chapman disapproved the California test or the way the California courts were interpreting that test is unclear. The issue of whether there is a difference between the "overwhelming evidence" and the "effect of the evidence" tests, and whether that difference matters, is born in Chapman: "The California-constitutional rule emphasizes 'a miscarriage of justice,' but the California courts have neutralized this to some extent by emphasis, and perhaps overemphasis, upon the court's view of 'overwhelming evidence.' We prefer the approach of this Court in deciding what was harmless error in our recent case of Fahy v. Connecticut." 386 U.S. at 23.

${ }^{36}$ The defense maintained an alternative position that if all constitutional error did not require automatic reversal, the error in their particular case was prejudicial. That position eventually prevailed. For the purpose of this article, the first position, automatic reversal, is of interest.

${ }^{37}$ With faithfulness to the constitutional union of the States, we cannot leave to the States the formulation of the authoritative laws, rules, and remedies designed to protect people from infractions by the States of federally guarànteed [constitutional] rights.... In the absence of appropriate congressional action, it is our responsibility to protect [federal constitutional rights] by fashioning the necessary rule.

386 U.S. at 21.

${ }^{38}$ All of these rules, state or federal, serve a very useful purpose insofar as they block setting aside convictions for small errors or defects that have little, if any, likelihood of having changed the result of the trial. We conclude that there may be some constitutional errors which in the setting of a particular case are so unimportant and insignificant 
proposition, he relied upon the harmless error statutes of the fifty states, observing that they failed to distinguish "between federal constitutional errors and errors of state law or federal statutes and rules." ${ }^{\text {39 }}$ These were the same harmless error statutes which he found inadequately designed to protect federally guaranteed rights. ${ }^{40}$ Commentators have observed that Chapman might be read to reject the method of measure-"overwhelming evidence"-the California court used in applying its harmless error statute. ${ }^{41}$ Others have suggested that the Chapman test is the measure for the federal harmless error statute. ${ }^{42}$ Some have concluded that the Chapman rule is a new constitutional incursion into matters properly the sole concern of the states. ${ }^{43}$ Still others have suggested that a later case, In re Winship ${ }^{44}$ requires application of the Chapman rule for all error-constitutional or not-in a criminal trial.

The Chapman test for harmless constitutional error, regardless of its foundation or justification, was the same test that Chief Justice Warren had "suggested" to the Connecticut court in Fahy: "Before a federal constitutional error can be held harmless, the court must be able to declare a belief that it was harmless beyond a reasonable doubt." ${ }^{24}$ In

that they may, consistent with the Federal Constitution, be deemed harmless, not requiring the automatic reversal of the conviction.

Id. at 22

39 "All 50 States have harmless-error statutes or rules, and the United States long ago through its Congress established for its courts the rule that judgments shall not be reversed for 'errors or defects which do not affect the substantial rights of the parties. " Id.

${ }^{40} \mathrm{Id}$.

${ }^{41}$ Much of Justice Brennan's dissent in Harrington v. California, 395 U.S. 250 (1969), takes this approach although it does not suggest that the California rule is at issue. Field, supra note 4, contains an extensive discussion of the "overwhelming evidence" measure and its applicability to current harmless error cases.

${ }^{42} R$. TrAynor, supra note 4 , at $37-42$.

${ }^{43}$ Chapman v. California, 386 U.S. at $45-46$ (Harlan, J., dissenting).

${ }^{44} 397$ U.S. 358 (1970). See Saltzburg, supra note 4, at 991. Professor Saltzburg's argument that any method of "overwhelming evidence" examination requires the appellate court to use a reasonable doubt test in order to comply with due process is persuasive. Id. at 1009-20. This position takes no account of the "class" of the error, but focuses upon the appellate fact review function and demands that the appellate jury be bound by the same test as the petit jury. He might have carried his point further. See text accompanying notes 64-109 infra for a discussion of the appropriateness of any appellate factfinding in a criminal case.

${ }^{45} 386$ U.S. at 24 adopting the Fahy test explicitly, Justice Black observed that "the beneficiary of a constitutional error" carried the burden of demonstrating that the error "did not contribute to the verdict."

Save for the reference to the harmless error statutes which grew out of the law reform movement of the early twentieth century, Justice Black presented no authority for the proposition that a constitutional violation might be harmless. His brief discussion of the statutes presents no clues as to what it is about their enactment or their foundation which would theoretically support a harmless constitutional error rule. ${ }^{47}$

Ironically, Justice Stewart, who dissented from the Court's interference with Connecticut's application of its own harmless error statute to the unconstitutional search in Fahy, and dissented from the Court's determination that the California comment rule "cost" Griffin anything he had not previously spent, ${ }^{48}$ argued that the Griffin error, being constitutional, required automatic reversal of Chapman's conviction. Justice Stewart's Chapman concurrence emphasized that, despite ample opportunity, the Court had never paused to inquire if a constitutional violation was harmful, reversing in most instances in which such a violation was found. He was not, however, willing to draw the harmlessness line between constitutional error and all other error. Noting that Griffin error did not present the appropriate vehicle for breaking with "settled precedent," 49 Justice Stewart indicated a willingness to place exclusionary rule error in the "all other" category. ${ }^{50}$

${ }^{46} I d$.

${ }^{47}$ Justice Black sat on both the Bruno and Kotteakos Courts and was as familiar as anyone with the history and purpose of the harmless error statutes which developed out of the law reform movement. He undoubtedly knew that the reason the statutes made no distinction between constitutional error and common error was that nobody proposing or passing the statutes ever dreamed that anybody would ever suggest that the "minutiae" with which they were dealing would include a constitutional guarantee. One can only speculate that Justice Black felt the need of some historical support and clutched at the first arguably relevant straw.

${ }^{48}$ Stewart's Griffin dissent was essentially a harmlessness approach in the first instance. He could not see how telling a jury something they already knew - that the defendant had not testified-could matter in the result. He was, therefore, unwilling to agree that the exercise of the fifth amendment right cost anything. 380 U.S. at 620-21 (Stewart, J., dissenting).

${ }^{49} 386$ U.S. at 45.

${ }^{50}$ Justice Stewart says that "constitutional rights are not fungible goods" as a preface to his position that while automatic reversal has been the rule, the right case might 
Just as Justice Stewart seemed to be willing to include certain constitutional error on the harmless error side, Justice Black seemed to concede that certain constitutional error requires automatic reversal. Without embracing the precedents, Black observed that "prior cases have indicated that there are some constitutional rights so basic to a fair trial that their infraction can never be treated as harmless error." $" 51$

Though Chapman may have left more questions than it answered, it established the possibility of a harmless constitutional error, wrapping the doctrine in the cloak of that harmless error doctrine which, in Justice Frankfurter's words, dealt with the "minutiae of procedure." 52

\section{The Sneak Thief}

Chapman received little notice when it was decided because many commentators agreed privately with the public assessment that "the possibility that a particular error will be found 'harmless beyond a reasonable doubt' seems slight." ${ }^{53}$ Only Justice Harlan expected Chapman to have any impact on judicial review of convictions, and his expectation was that the federal courts would become increasingly involved in what he considered to be "state-judicial domains."

present a place for harmless error. His only example, and obvious choice for the place, is the exclusionary rule. While he speaks in terms of a constitutional right, it is clear that he does so by force of precedent rather than personal conviction. His footnote to the subject leads one to believe that he is more interested in returning the exclusionary rule to the realm of common error than he is in creating a harmless constitutional error rule. Id. at 44 n.2.

${ }^{51} 386$ U.S. at 23. Justice Black cites three examples, id. at 23 n.8: Gideon v. Wainwright, 372 U.S. 335 (1963) (right to counsel); Payne v. Arkansas, 356 U.S. 560 (1958) (coerced confession), and Tumey v. Ohio, 273 U.S. 510 (1927) (impartial judge). Justice Stewart cites additional instances in which automatic reversal is indicated. Justice Black gives no reason for those he selects, does not necessarily endorse the result, and provides no clue as to what characteristic unifies the cases past his "so basic to a fair trial" language. Given his total incorporation approach to due process, see Adamson v. California, 332 U.S. 46 (1947) (Black, J., dissenting), it is unlikely that he means to suggest that there is a constitutional difference among rights found within the first eight amendments. His citation, like Justice Stewart's, may be the result of frustration with the process of trying to set a code of procedure from the Bill of Rights, and striking a reasonable balance between clear rules and flexible application.

${ }^{52}$ Bruno v. United States, 308 U.S. 287, 294 (1939).

${ }^{53}$ The Supreme Court, 1967 Term, 81 HaRv. L. REv. 205 (1967).

${ }^{54} 386$ U.S. at 57 (Harlan, J., dissenting). were wrong. The "slight" possibility became a common occurrence in both the state and federal courts, ${ }^{55}$ and the federal courts did not use Chapman as a tool for fixing their own notion of "harm" upon state courts with contrary views. There is some irony in the fact that, on the contrary, Chapman became the magic formula by which the state courts found harmless constitutional error in record numbers-findings to which the federal courts gave substantial deference. ${ }^{56}$

Although Chapman remains the most commonly cited authority for the proposition that any particular constitutional error is harmless, it may not be accurate to ascribe the significant evils of the doctrine to the Chapman opinion. Although Chapman introduced the harmless constitutional error, the doctrine as presented possessed only the potential, not the doctrinal structure, for constitutional and institutional mischief. Traynor thought the Chapman test to be so stringent as to be tantamount to an automatic reversal rule. ${ }^{57} \mathrm{Had}$ the Supreme Court interpreted and the other appellate courts applied Chapman to allow a finding of harmlessness only after an appellate court had examined the error alone and found beyond a reasonable doubt that it could not have contributed to the verdict, the predictions of inconsequence might have proven correct. Cases decided after Chapman relaxed the rigor of the test and applied it to circumstances which could not have been contemplated, and indeed, would have been disavowed by the Chapman majority.

Any new doctrine or exception to an established doctrine must be expected to grow past the parameters set in the decision which created it. The harmless constitutional error doctrine has a char-

${ }^{55}$ The data from Harmful Use, supra note 3, at 544-48, on the incidence of harmless error indicate the federal courts perhaps were as anxious as the state courts to use a mechanism which would allow them to find a constitutional error and still affirm the conviction.

${ }^{56}$ Because a finding that an error is harmless is a factual determination, there is little realistic opportunity for review by the federal courts of a state appellate court decision. An interesting exception is the kind of case where the state appellate court finds an error harmless and the federal court need not second guess the state appellate court's reading of the statute in order to find that there was harm in the error. Allison v. Gray, 603 F.2d 633 (7th Cir. 1979), is an example of such a case. The Wisconsin Supreme Court found that the failure to allow a defendant to present alibi testimony was error, but harmless. Allison v. State, 62 Wis. 2d 14, 214 N.W.2d 437 , cert. denied, 419 U.S. 1071 (1974). The Seventh Circuit reversed, noting that the Wisconsin court could not possibly judge the weight or effect of alibi evidence that was not in the record.

${ }^{57}$ R. TRAYNOR, supra note 4 , at 43 . 
acteristic unique among doctrines with constitutional impact that makes such growth immediate, indiscriminate, and unpredictable. It has no substantive doctrinal base. As a result, the doctrine has become a major thief of constitutional rights without any particular notice or analysis. Unlike the substantive constitutional decisions such as $\mathrm{Mapp},{ }^{58}$ Miranda, ${ }^{59}$ and $W a d e,{ }^{60}$ or even the procedural constitutional decisions such as Linkletter v. Walker, ${ }^{61}$ harmless constitutional error carries with it no legal issue of primary concern to an appellant. Appellants are unable to launch a consistent and effective attack against the doctrine because no single appellant has any doctrinal stake in the issue. Each appellant hopes only to avoid the factual trap of harmless constitutional error. He has little opportunity to challenge on the factual issue, let alone on the propriety of the doctrine. ${ }^{62}$ Consequently, the courts failed to provide analysis in the development of harmless constitutional error. That failure has created an appellate procedural doctrine which has caused "mischief"63 beyond anyone's expectations. The doctrine has created appellate factfinding which denies the constitutionally guaranteed right to trial by jury. In addition, the doctrine erodes constitutional principles at all levels of the criminal justice system from prosecution to Supreme Court review without ever affording an opportunity for a hearing on the merits of the principle eroded.

\section{III. “ . . . A FAMILIAR STANDARD"64}

Justice Black's observation that the reasonable doubt standard was a familiar one to appellate

$$
\begin{aligned}
& { }^{55} \text { Mapp v. Ohio, } 367 \text { U.S. } 643 \text { (1961) (searches). } \\
& { }^{59} \text { Miranda v. Arizona, } 384 \text { U.S. } 436 \text { (1966) (confes- } \\
& \text { sions). } \\
& { }_{60} \text { United States v. Wade, } 388 \text { U.S. } 218 \text { (1967) (line } \\
& \text { ups). }
\end{aligned}
$$

381 U.S. 618 (1965) (retroactivity).

${ }^{62}$ The nature of the harmless error determination is such that an appellant cannot argue its inapplicability without an implicit concession that the inquiry is justified and without taking valuable time and energy away from persuading the court that there is error in the first instance. Further, few appeals proceed with the full record available to the appellate court or sufficient time for the appellant to adequately parse the record to establish the harmlessness of an error that the appellate court has not yet found.

${ }^{63}$ Justice Black anticipated that harmless error rules could create "mischievous results when, for example, highly important and persuasive evidence, or argument, though legally forbidden, finds its way into a trial in which the question of guilt or innocence is a close one." 386 U.S. at 22. He did not anticipate the mischief which the doctrine might bring to the appellate process or to constitutional guarantees.

64 "While appellate courts do not ordinarily have the courts identifies precisely the problem which arose after the Supreme Court decided Harrington v. California. ${ }^{65}$ Appellate courts never operate as factfinders for matters which must be determined beyond a reasonable doubt. They rarely operate as fact-finders at all. ${ }^{66}$ Most importantly, until the Court approved the "overwhelming evidence" approach to harmless constitutional error, no court had the power to enter a guilty verdict on its own judgment when the defendant properly exercised his right to a trial by jury. ${ }^{67}$

Because Chapman seemed to reject the California court's "overwhelming evidence" approach to harmless error, and to approve a test that required the court to focus instead on whether the error contributed to the verdict, Glenn Harrington's murder conviction would likely not stand. Harrington, a caucasian, and three blacks were jointly tried and convicted of murder. Each of Harrington's alleged accomplices confessed. Their confessions were admitted at the trial in violation of the rule of Bruton v. United States, ${ }^{68}$ prohibiting the introduction, against a codefendant, of another's confession when that other individual did not take the stand and thereby submit to confrontation by his codefendant. It is difficult to imagine how any court, focusing only upon the illegally admitted confessions, could determine beyond a reasonable doubt that the confessions of the accomplices did not contribute to Harrington's conviction-particularly when those confessions described the fourth participant as "the white guy." Harrington made

original task of applying such a test, it is a familiar standard to all courts...." Id. at 24.

${ }^{65} 395$ U.S. 250 (1969).

${ }^{66}$ Rule 52 of the Federal Rules of Civil Procedure is exemplary of the reticence of appellate courts to review, let alone make initial determinations of fact. "Findings of fact shall not be set aside unless clearly erroneous, and due regard shall be given to the opportunity of the trial court to judge the credibility of the witnesses." FED. R. Crv. P. 52(a).

${ }^{67}$ The appellate court's action in finding an error harmless by assessing the weight of the remainder of the evidence is not, in a technical sense, the direction of a verdict nor the granting of a judgment n.o.v. to the government. However, it is a determination of guilt upon facts which have never been considered by a jury and which, given the appellate court's finding of guilt, never will be.

${ }^{68} 391$ U.S. 123 (1968).

${ }^{69}$ None of the defendants mentioned Harrington by name. The Court, however, accepted Harrington's argument that, when the defendants said "the white guy," there was not much doubt who the speaker had in mind as Harrington sat in the dock with three blacks. 395 U.S. at 253. 
statements which, according to the Court, "fell short of a confession but which placed him at the scene of the crime. ${ }^{, 70}$ According to Justice Douglas, writing for a five-member majority, those statements and other evidence were "so overwhelming" that the admission of the co-defendant's confession was harmless beyond a reasonable doubt. $^{71}$

The Harrington majority, which included Justice Black, the author of Chapman, stated emphatically that they did not "depart from Chapman; nor ... dilute it by inference." J2 Justice Brennan, joined by Chief Justice Warren and Justice Marshall, took exception, contending that Chapman had been overruled: "The Court today by shifting the inquiry from whether the constitutional error contributed to the conviction to whether the untainted evidence provided 'overwhelming' support for the conviction puts aside the firm resolve of Chapman ...."73

Harrington was followed by the remarkably similar case of Schneble v. Florida. ${ }^{74}$ Although the dissenters, including Justice Douglas, the author of Harrington, complained bitterly that Schneble's reliance upon Harrington was misplaced, the majority used the "overwhelming evidence" approach that Justice Douglas had adopted for the Harrington facts. ${ }^{75}$ In addition, Justice Rehnquist's pointed use of "probability" "language from the Harrington decision, plus his own peculiar phrasing of the Chapman holding, ${ }^{77}$ left the burden of proof unclear, both as to what it was and who was to carry it. After Schneble, one may argue reasonably that an appellate court faced with an error of constitutional

${ }^{70}$ Id. at 252

${ }^{71} I d$. at 254.

${ }^{72}$ Id.

${ }^{73} I d$. at 255 (Brennan, J., dissenting).

74405 U.S. 427 (1972).

75 "Not only is the independent evidence of guilt here overwhelming, as in Harrington. ..." Id. at 431.

${ }^{76}$ Although it is unlikely that Justice Douglas intended to change the test from beyond a reasonable doubt to one of probability, he used language in Harrington which Justice Rehnquist was able to use to support such a change: "Our own reading of the record and on what seems to us to have been the probable impact ... on the minds of an average jury." Id. at 432 (quoting Harrington v. California, 395 U.S. at 254).

${ }^{77}$ Justice Black put the burden of demonstration upon the prosecution, "requiring the beneficiary of a constitutional error to prove beyond a reasonable doubt that the error complained of did not contribute to the verdict obtained." 386 U.S. at 24. Justice Rehnquist implied that the demonstration must be made by the defendant: "Thus, unless there is a reasonable possibility that the improperly admitted evidence contributed to the conviction, reversal is not required." 405 U.S. at 432. dimension should make its own independent evaluation of the evidence, and reverse the conviction only if it was persuaded that the average jury would have changed its verdict had the illegal evidence been excluded. ${ }^{78}$ By a subtle rearrangement of words and ideas, Justice Rehnquist converted a test which forced the prosecution to show beyond a reasonable doubt that the error did not contribute to the verdict, into a test which forced the defendant to show that the error was of such significance that without it the defendant would be entitled to a directed verdict of acquittal. ${ }^{79}$

Most of the commentary concerned with harmless constitutional error has focused upon subclasses of constitutional rights which, in the minds of the commentators, ought to be exempt from harmless error analysis. ${ }^{80}$ These commentators focused on the nature of the constitutional right violated rather than the nature of the process by which the harmlessness is determined. ${ }^{81}$ For the most part they follow Justice Black's position and have concentrated on constitutional error which affects the "process" of the trial, such as failure of counsel or discrimination in the selection of a jury panel, rather than on those errors which affect the amount of evidence presented. They have argued that when a violation of the right is either harmless by definition-jury access ${ }^{82}$-or beyond precise determination-effective assistance of counsel ${ }^{83}$-harmless

${ }^{78}$ Chief Justice Burger's opinion in Holloway v. Arkansas, 435 U.S. 475 (1978), rejects the contention that harmless error analysis is appropriate when a defendant raises a failure of effective assistance of counsel due to a conflict of interest. His rejection is based upon the proposition that "a rule requiring the defendant to show that a conflict of interests ... prejudiced him ..." would not be susceptible to evenhanded application as is required in harmless error analysis. There can be little doubt from his explanation that he considers the defendant to have the burden of demonstration with respect to harmless error.

${ }^{79}$ Justice Rehnquist's statement that "[i]n this case, we conclude that the 'minds of an average jury' would not have found the State's case significantly less persuasive had the testimony as to Snell's admission been excluded," can only be read in the context of his opinion to mean that the jury verdict would not have been different. 405 U.S. at 432 . The effect is to make the harmless constitutional error test the equivalent of a guilty or not guilty determination, allowing only those who can demonstrate to the appellate court that they are not guilty as a matter of law-that is, can demonstrate a reasonable doubt as to the entire case-to gain a new trial when constitutional rights are abridged.

${ }^{80}$ See, e.g., Mause, supra note 4.

${ }^{81}$ See, e.g., Note, Harmless Constitutional Error, 20 STaN. L. Rev. 83 (1967).

${ }^{82}$ Field, supra note 4 , at 19-20.

${ }^{83}$ Mause, supra note 4 , at 541 . 
constitutional error analysis is inappropriate. None has suggested that the harmless constitutional error process itself violates the defendant's right to a trial by jury. ${ }^{84}$

When an appellate court tests for harmlessness by reviewing the record to determine whether the remainder of the evidence is so overwhelming that the error did not contribute to the verdict, it sits as an appellate jury. ${ }^{85}$ The test assumes that the error made a difference in the amount of evidence presented to the jury. ${ }^{86}$ When the appellate court

${ }^{84}$ Professor Saltzburg has suggested that the Chapman rule is required for all error in a criminal case-be it constitutional or common-by virtue of the due process clause and the right to trial by jury. Saltzburg, supra note 4, at 991-93. Professor Mause briefly raised the possibility that the jury trial guarantee made any harmless constitutional error rule unconstitutional, but rejected the proposition because nothing requires a state to provide appellate review of any kind in a criminal case. Mause, supra note 4, at 531-32. Professor Saltzburg raised the same problem for his proposition that the jury trial right precluded any test but Chapman's reasonable doubt test for all error in criminal trials. Saltzburg, supra note 4, at 1028. Saltzburg was probably correct with respect to common error. Mause was undoubtedly wrong with respect to constitutional error. States cannot avoid federal review, upon habeas corpus, for error of a constitutional nature. It follows that any jury trial problem resulting from application of a harmless error rule cannot be set aside for constitutional error, although it may be for common error.

${ }^{85}$ Professor Field, supra note 4, at 39, suggests that the Harrington test is not really "overwhelming evidence" but "cumulative evidence." Whatever merit there may be to the distinction, the appellate court must, in the first instance, make a judgment about the quantity or quality of the remainder of the evidence. Professor Saltzburg, supra note 4 at $1014, n .89$, argues that there is no practical difference between the effect of the evidence test and the overwhelming evidence test so long as the appellate court uses a "virtually certain" or beyond a reasonable doubt test on the remainder of the evidence. He maintains that in any instance where the overwhelming evidence test leaves the Court with the belief that the defendant is guilty beyond a reasonable doubt it would also find that the error had made no contribution to the verdict. While that may often be the case, it is not necessarily so. For example, in Allison v. Gray, 603 F.2d 633 (7th Gir. 1979), the evidence would leave the average skeptic convinced of the defendant's guilt. However, the error was failure to allow the defendant to present alibi evidence. Under the effect of the error test, the exclusion of the defendant's evidence could never be harmless. Regardless of whether it would often lead to the same result, the appellate activity in the effect of the evidence test is a traditional appellate exercise of determining a factual "could" by assuming all facts in a light most favorable to the party without the appellate burden, while in the overwhelming evidence test the court is reaching an original fact judgment.

${ }^{86}$ Professor Field suggests that the overwhelming evi- decides that the evidence presented to the jury minus (or plus) the evidence produced (or excluded) by the error, it is the only factfinder which has ever made a guilty/not guilty judgment about the new amount of evidence.

An appellate court's determination that a set of facts supports a guilty verdict, in the first instance, is unprecedented. The failure of precedent reflects a consistent and long term judgment about the wisdom and constitutionality of such an appellate determination. For reasons so familiar that Justice Brennan did not think repetition was necessary in Harrington, appellate courts restrict their factfinding activity to the review of what a previous factfinder found. ${ }^{87}$ The review is limited to determinations that the factfinder's conclusion cannot be justified even when all of the evidence is viewed in a light most favorable to the conclusion. ${ }^{88}$

An appellate court defies common sense when it steps out of its traditional role as a reviewing court and attempts to operate as a primary factfinder. Appellate review of an entire trial transcript is an incredibly inefficient use of appellate court time. To pursue such a course in order to determine whether error is harmless, so that judicial economy might be served is not only ironic, it is nonsensical. ${ }^{89}$ In addition, unless the litigants are placed on

dence test may be applicable to constitutional errors at trial which do not affect the amount of evidence presented to the jury. Field, supra note 4 , at 16 . None of the Supreme Court decisions finding harmless constitutional error has involved an error which did not affect the amount of evidence. Those cases to reject harmless constitutional error treatment for particular error have involved errors which did not quantifiably affect the amount of evidence. While the necessary speculation involved with such analysis has never been assigned as a reason for excluding all such error from harmlessness analysis, it seems to be the rationale from case to case. See, e.g., Holloway v. Arkansas, 435 U.S. 475 (1978).

${ }^{87} 395$ U.S. at 257 (Brennan, J., dissenting). See discussion at text accompanying notes 91-98 infra, for the oftcited factors militating against appellate factfinding.

${ }^{88}$ Justice Rehnquist misused the familiar sufficiency of the evidence test in Schneble v. Florida, 405 U.S. 427. He relied upon Rogers v. Missouri Pacific Ry. Co., 352 U.S. $500(1957)$, to support a factfinding presumption in favor of the government on an issue for which it had the burden of proof. 405 U.S. at 432 . Justice Marshall, in dissent, wasted no time in pointing out that the appellate function in determining the sufficiency of the evidence in a civil case was exactly the opposite of the function set out by the harmless error test, and employed a presumption exactly opposite of that underlying the reasonable doubt burden. 405 U.S. 433-34.

${ }^{89}$ Justice Stewart, concurring in Chapman, alludes to the difficulty of an appellate court reviewing each transcript from case to case in order to determine harmless- 
notice that the error is conceded and harmlessness is the only issue, the appellate court must review the entire transcript and make a determination without the benefit of the litigants' view of the facts-a substantial departure from the normal method of appellate review. To the extent that appellate time is saved by the litigants' shaping and narrowing the issues, the inability of the litigants to contribute to the appellate decisionmaking process harms the litigants and wastes court time. Unless the courts adopt a policy of total fact review first and legal issue second ${ }^{90}$ the appellate court cannot begin the time-consuming task of fact review until it has taken the time to perform its traditional function of reviewing for and, in this case, finding error. From the perspective of efficient appellate practice only-judicial economy of a kind-the harmless constitutional error doctrine involves a tremendous increase in appellate court time and a diminution of the traditional assistance that counsel provides.

From an institutional perspective, the time cost is not as substantial as the cost in justice. Appellate courts are, by their position as dispassionate and removed arbiters of the law, extremely poor finders of fact. Appellate courts' deference to trial court factfinding is not a matter of accident. ${ }^{91} \mathrm{~A}$ cold record, assuming that it is accurate, cannot substitute for a trial. Every trial lawyer knows that the "facts" of demeanor are at least as important as the "facts" of testimony. An appellate court reading a record in its entirety ${ }^{92}$ knows nothing of the unreasonable pause, the inappropriate smile, the sarcasm that changes a "sure" which means "yes"

ness, and then candidly admits that " $\mathrm{t}]$ his burdensome obligation is one that we here are hardly qualified to discharge." 386 U.S. at 45.

${ }^{90}$ In Milton v. Wainwright, 407 U.S. 371 (1972), over the vigorous dissent of four justices, Chief Justice Burger stood appellate procedure on its head. He assumed the error-the real question in the case-and proceeded, so he said, to review the entire record to make a harmlessness determination.

91 "Such deference is particularly apposite because the trial judge and jury are closest to the trial scene and thus are afforded the best opportunity to evaluate contradictory testimony." Mincey v. Arizona, 437 U.S. 385, 408 (1979) (Rehnquist, J., dissenting).

${ }_{92}$ There is no way to insure that judges read the entire transcript. Given the volume in most appellate courts, it stretches the imagination to believe that even one of the judges would read the entire record. In fact, most matters come to appellate courts with abbreviated records collected in an appendix by litigants to whom harmlessness has not occurred. The appendix and record are chosen for relevance to the legal issues raised. Good practice and appellate rules encourage the abbreviated record. to a "sure" which means "I don't believe that" or "I don't agree." Appropriately, every trial court instructs the jury that it is the sole judge of witness credibility. Rule 52's admonition that appellate courts in civil cases shall give "due regard ... to the opportunity of the trial court to judge the credibility of the witnesses" ${ }^{\prime 93}$ is no accident. One of the problems with appellate factfinding is that the appellate court is likely to be wrong.

The greatest cost of the harmless constitutional error $^{94}$ rule is its usurpation of the jury function. Aside from the likelihood of erroneous factfinding because a cold record is a poor communicator, an appellate court is far removed from being a jury, and jury trials comprise the heart of our criminal justice system. We are probably better off with juries making "wrong" decisions than with judges making "right" ones. ${ }^{95}$ The decisionmaking gulf between three appellate judges reading a transcript at their leisure in chambers and twelve citizens locked in a jury room is not bridged by an appellate judge's intellectual understanding of the reasonable doubt standard. In comparing the appellate jury to the petit jury some questions should be asked. Which defendant, let alone the defendant's lawyer, would demand a jury trial and then allow an appellate judge to sit on the jury? Even with the limited voir dire available in most federal courts, if a lawyer were foolish enough to seat an appellate judge on a jury, would the lawyer do so

${ }^{93}$ Fed. R. Crv. P. 52(a).

${ }^{94}$ Justice Harlan, in his Fahy dissent, points out that a nonconstitutional error can be as prejudicial to a defendant as a constitutional error, and in some instances, more so. 375 U.S. at 94 . Professor Saltzburg, supra note 4, at 989-90, makes the same point in arguing for the same harmless error rule in criminal cases involving constitutional and common error. While the automatic reversal rule for harmless constitutional error does not suffer from the same vulnerability to the "appellate review not required" argument as does harmless common error, the potential for denial of a jury trial exists as strongly for common error as it does for constitutional error when the character of jury justice (as opposed to appellate justice) is at issue.

${ }_{95}$ Justice Harlan, in a rare example of poor judgment, once suggested that "untrained jurors are presumably less adept at reaching accurate conclusion of fact than judges. ... " Duncan v. Louisiana, 391 U.S. 145, 188-89 (1968) (Harlan, J., dissenting). Even if true, the value in citizen participation may outweigh the value of a decisionmaking system which makes more correct decisions. In the law generally, and in criminal law particularly, the societal acceptability of the decision may be more important than its correctness. Juries represent an institutional insurance policy for the continued acceptability of the decisionmaking system. 
without some voir dire? Would the lawyer at least find out who the judge was before failing to exercise a peremptory? ${ }^{96}$ Assuming a lawyer who would try a factual defense to a jury of appellate judges, would he agree to waive summation? ${ }^{97}$ Would that lawyer allow the appellate jury to know that a previous jury found the defendant guilty? Would the lawyer agree that group decisionmaking means nothing and that the jury members could go back to their offices and.read through notes at their own pace until they reach a decision? Would the lawyer agree that jury nullification was of no particular value to the defendant? ${ }^{98}$ Any lawyer who might agree to all of the above would not have much quarrel with a three-person jury finding the defendant guilty, two-to-one.

Duncan v. Louisiana, ${ }^{99}$ decided a year after Chapman, held that the right to a trial by jury was one of those fundamental rights which not even the existence of state boundaries could destroy. Presumably it would be one of those rights "so basic to a fair trial"100 that even Justice Black would consider harmless error analysis to be inappropriate. In deciding that a trial judge's decision that Gary Duncan was guilty of simple battery beyond a reasonable doubt could not be squared with the sixth amendment right to a jury trial, Justice White reviewed the history of American juries. $\mathrm{He}$ assigned "oppression by the Government" and "protect[ion] ... against judges" as two of the major reasons for the insistence upon the right to jury

${ }^{96}$ A danger exists that when harmlessness is at issue the appellate lawyer who decides to argue harm is making his pitch to the jury's "boss," not the jury. If long transcripts are to be read, clerks are likely to do the reading, not judges.

${ }^{97}$ Because harmlessness is rarely at issue in briefs or at argument, the defense lawyer never gets to argue the facts and the law to the appellate jury. Even if the opportunity is there, the judges have not yet read the record, and the lawyer is arguing from factual thin air. Additionally, in criminal cases much of the argument for the defendant is related to the burden of proof. There is no opportunity to make that argument, and there is some reason to believe that appellate judges are in more need of the refresher than some juries. See, e.g., Milton v. Wainwright, 407 U.S. 371 (1972).

${ }^{98}$ Jury nullification is not a particularly common event, and may not often be affected by an evidence error. However, there may be circumstances in which a jury failed to exercise its power to nullify the law because the error admitted evidence that dissuaded it from nullification, or excluded evidence which, if heard, would have persuaded the jury to nullify.

${ }^{99} 391$ U.S. 145 (1968).

100 Justice Black's description of those errors which the Court had found to require automatic reversal. 386 U.S. at 23. trial in criminal cases. ${ }^{101}$

After Duncan, the Court spent some time deciding exactly how many people were needed for a jury, what constituted an impartial jury, ${ }^{102}$ and how many of those impartial jurors had to agree before a criminal verdict was proper. While there was substantial disagreement, no Justice on the Court ever suggested that three is enough to make a jury, that less than six votes is enough to convict, or that appellate judges are diverse enough to constitute a community cross section. Although Williams v. Flor$i d a^{103}$ held that the jury guaranteed by Duncan need not be made up of twelve persons, and Apodaca $v$. Oregon $^{104}$ allowed that a criminal jury need not be unanimous, Burch v. Louisiana ${ }^{105}$ made it clear that the sixth amendment required a jury as small as six persons to be unanimous before it could return a guilty verdict. ${ }^{106}$ Furthermore, Taylor $v$. Louisiana $^{107}$ and Duren v. Missouri ${ }^{108}$ established that the defendant's sixth amendment right to an impartial jury meant that the jury must be drawn from a fair cross section of the community. An appellate court of three, deciding guilt by a vote of two-toone is hardly a jury.

The effect of the decisions in Harrington and Schneble, and their approval of the overwhelming evidence approach to harmless constitutional error is to deny the defendant/appellant a right to a trial by jury. The appellate court, by definition, sits as a jury and makes a guilt determination based upon an amount of evidence upon which no jury has passed. While double jeopardy in the classic sense is not involved, a certain discomfiture lies in an appellate court's determination that a lower appellate court erred in its judgment that an error was not harmless. ${ }^{109}$ Lastly, there is, at a minimum, some embarrassment in a decision

101391 U.S. at 155-56.

${ }^{102}$ The sixth amendment guarantees, among other things: "... trial, by an impartial jury." U.S. ConsT. amend. VI.

${ }^{103} 399$ U.S. 78 (1970) (approving a jury of six).

${ }^{104} 406$ U.S. 404 (1972) (approving a guilty verdict by ten-to-two jury votes).

105441 U.S. 130 (1979).

${ }^{106}$ Ballew v. Georgia, 435 U.S. 223 (1978), somehow discerned a constitutional difference between six and five, allowing a jury of six, but not of five.

${ }^{107} 419$ U.S 522 (1975).

${ }^{108} 439$ U.S. 357 (1979).

109 The dissent in Milton v. Wainwright, 407 U.S. at 378 , pointed out that no less than four other courts had considered the matter and none had found the error to be harmless. If each used the "overwhelming" evidence test, only the Supreme Court-five-to-four-believed that the untainted evidence proved guilt beyond a reasonable doubt. 
which says that an error was harmless beyond a reasonable doubt: five-to-four.

\section{Second Story Job on the Constitution}

The harmless constitutional error doctrine works only a petty theft on individual defendants' rights in specific cases but its consistent application exerts a more profound effect upon society. The harmless constitutional error rule, regardless of the test, militates against basic freedoms and controls upon governmental institutions that operate against individuals. At all levels of the criminal justice system, the harmless constitutional error rule dilutes the impact of most constitutional criminal procedure decisions of the last quarter century which preserve individual rights against contrary claims of necessity by the government. The rule allows an ad hoc, after the fact, factual judgment by an appellate court which makes it difficult for an individual to attack it and diminishes the level of protection provided by specific constitutional provisions without affording any opportunity to argue the issue's merits. If, as some claim, many of the Warren Court decisions of the 1960s were ill-advised, if the society has, indeed, been damaged by the change in the relationship between the individual and the state as incarcerator, that is a matter to be addressed on the merits, not through the procedural backdoor of harmless constitutional error.

Harmless constitutional error is particularly inappropriate because of the special relationship between the Constitution and the courts. All of the assumptions necessary to support any harmless error doctrine are inapplicable when the error at stake abrogates a constitutional right. Any doctrine which allows an appellate court to identify an error and then find it "harmless" assumes that the appellate function is limited to the correction of an inappropriate trial court result. Further, it assumes the decision will affect the litigants alone. ${ }^{110}$ The harmless error doctrine assumes that any other interest, other than the correction of an inappropriate trial result, is sufficiently insignificant to balance unfavorably against the nonconstitutional value of judicial economy. ${ }^{111}$

${ }^{110}$ While the result might affect future and unknown litigants, it is the litigants in the case or those that may someday be similarly placed that are affected, to the exclusion of the public in general.

${ }^{111}$ A public interest exists for every law, including the Missouri constitutional requirement which caused the reversal of Campbell's case for want of a "the" in the indictment. State v. Campbell, 210 Mo. 202, 109 S.W.
At least since Marbury v. Madison, ${ }^{112}$ the Supreme Court obligation of judicial review has been the lifeblood of the living Constitution. Justice Harlan's Chapman dissent decries what he sees as the Court's "assumption of what amounts to a general supervisory power over the trial of federal constitutional issues in state courts, ${ }^{113}$ but he is a lone voice. Justice Black left little doubt that federalism concerns are insufficient to justify state interference with rights emanating from the federal Constitution. ${ }^{114}$

The special relationship between the Constitution and the Court, in which each gains its strength from the other, is unique when the rights in question are those enumerated in the first eight amend. ments. One does not have to accept Justice Black's theory of total incorporation ${ }^{115}$ to recognize that the first eight amendments are antimajoritarian and antigovernment. In the American system, the courts historically have been the only institution sufficiently separated from the political system to act as the preserver of those antimajoritarian and antigovernmental rights. The cost of that preservation has never been small: "The criminal is to go free because the constable has blundered."116

If certain errors are to be susceptible to harmless error treatment and others are not, ${ }^{117}$ the Consti-

706 (1908). The harmless error rule assumes that whatever that interest may be it is of less weight than the interest in judicial economy.

1125 U.S. (1 Cranch) 137 (1803).

${ }^{113} 386$ U.S. at 46-47 (Harlan, J., dissenting).

${ }^{114}$ See note 37 supra.

115 Justice Black argued that the first eight amendments were totally incorporated into the due process clause of the fourteenth amendment and were thereby applicable to the states. His position, most fully set out in his dissent in Adamson v. California, 332 U.S. 46, 68 (1947) (Black, J., dissenting), never held a majority of the Court. Ironically, his position was set out in opposition to the due process approach of Cardozo, Frankfurter, Harlan and others, which inquired as to whether the matter at issue was fundamental to the American concept of criminal justice. His language in Chapman, "so basic to a fair trial," comes perilously close to the Cardozo-Frankfurter-Harlan concept of distinguishing between rights based upon "fundamentalism."

${ }^{116}$ People v. DeFore, 242 N.Y. 13, 21, 150 N.E. 585, 587 (1926) (opinion of Cardozo, J.).

117 Justice Black, by his Chapman acknowledgment of the Court's prior decisions, Justice Stewart, by his desire to exclude the fourth amendment, and the many commentators by their various selections have all agreed that there are some constitutional errors which ought to be subject to the harmless error approach and others which should not. None has presented a particularly persuasive reason for discrimination between constitutional errors. 
tution is the only reasonable place to draw the line. ${ }^{118}$ The efficacy of that line is based upon the assumptions of both the harmless error doctrine and the system of constitutional jurisprudence. There are three major differences between nonconstitutional and constitutional rights which demand distinction between them when the appropriateness of harmless error analysis is at issue.

First, nonconstitutional rights, the abrogation of which create trial error, are transitory and political. They are legislatively created, maintained, 'and changed. Their preservation is ensured by the ultimate safeguard of majority approval, or at least political process approval. Constitutional rights, on the other hand, are immune to the political process, at least as to preservation. ${ }^{119}$ Legislators and electorates have no function in the preservation of constitutional antimajoritarian and antigovernmental individual rights. The courts, rightly or wrongly, are the sole institution for maintenance and change. ${ }^{120}$

Second, nonconstitutional rights likely to be implicated in trial error are, generally, of a kind for

${ }^{118}$ Justice Harlan compellingly argues that the Chapman decision, to the extent it conceives "of an application of harmless-error rules as a remedy designed to safeguard particular constitutional rights," 386 U.S. at 50 (footnote omitted) (emphasis added), is unsupportable. As a device to insulate only some constitutional rights from application of state harmless error rules, a federal harmless error rule has little to recommend it. Neither Black nor Stewart suggests a rationale for the application of the stricter test to some constitutional rights. Once the judgment is made that all constitutional rights are beyond harmless consideration, Harlan's complaint about a failure of reason is gone. Perhaps he would disagree with a result which put all constitutional error beyond the reach of harmless error, however, clearly he agrees with the proposition that the nature of the Court's relationship to the Constitution makes the question of the validity of a harmless error rule a federal constitutional question unaffected by the nature of the specific constitutional right.

${ }^{119}$ Concededly, constitutional rights are subject to the political process through the power of amendment, but the political activity relates to repeal and addition rather than preservation. The political process possibly could destroy a constitutional right such as the fourth amendment, but the political process of constitutional amendment probably could not preserve the right.

${ }^{120}$ In the fourth amendment context, a number of commentators have suggested that the executive might protect and preserve the privacy of citizens more effectively than the exclusionary rule. See, e.g., Kaplan, The Limils of the Exclusionary Rule, 26 Stan. L. REv. 1027 (1974). While there might be a chance, it is a little like putting the foxes in charge of the chicken coop. It indulges the assumption that there is no need for the antigovernment provision in the first instance. which society has little, if any, interest outside of the conduct of the trial. ${ }^{121}$ Constitutional rights often implicate substantial societal interests exclusive of the error in a particular trial. In those cases where the defendant stands as society's surrogatesearch cases, for instance-society's interest in the right has nothing to do with the trial result. The society's interest in the right is furthered, or not, by the result of the suppression hearing. ${ }^{122}$

Finally, nonconstitutional rights which are abrogated by trial error are usually neutral. They are as likely to benefit the government in a given trial as they are the defendant. Hearsay, for example, may benefit the government in one instance and the defendant in another. Constitutional rights, such as the right to confrontation, which might be abrogated by a trial error, are always beneficial to the defendant and consistently restrictive with respect to the government's case. Each of these three differences has institutional consequences which differentiate common error from constitutional error when the appropriateness of a harmless error doctrine is the issue. The harmless constitutional error doctrine has interfered with the Supreme Court's task of interpreting the Constitution, and may have, in one instance, changed other interpretations without notice.

Harrington and Schneble were both "confrontation" cases and represent a line of cases which demonstrates two ways in which the harmless constitutional error doctrine interferes with the orderly development of constitutional law. Bruton v. United States, ${ }^{123}$ decided one year after Chapman and before Harrington, overruled Delli Paoli v. United States. ${ }^{124}$ Delli Paoli allowed the confession of a codefendant in a joint trial to be offered despite the fact that the individual did not testify. The Court held an instruction to the jury that the confession could be considered only against the confessing codefendant sufficiently protected the other defendant's right to confrontation. The Bruton Court, speaking through Justice Brennan, held that the instruction to disregard would not suffice in protecting the other

${ }^{121}$ Obviously, some state rules affect conduct outside the scope of the trial, for example, a requirement that a confession be signed. Most nonconstitutional trial errors, however, will involve rules designed for the conduct of trials.

${ }^{122}$ This is not intended to imply that society has no interest in the trial result, but only that it has a distinct interest in the fourth amendment protection. It is that distinct interest which is not within the assumptions underlying the harmless error rule.

${ }^{123} 391$ U.S. 123 (1968).

${ }^{124} 352$ U.S. 232 (1957). 
defendant's right to confrontation. In reaching that conclusion, Brennan made an observation which, though true, was ignored the next year in Harrington: "We, of course, acknowledge the impossibility of determining whether in fact the jury did or did not ignore [the] statement inculpating petitioner in determining petitioner's guilt."125 Although both Douglas' majority opinion and Brennan's dissent in Harrington concentrated on the effect of the decision on Chapman, Harrington changed what appeared to be the basis for Bruton: The court can never be sure of the jury's response to a codefendant's confession, and, therefore, it will take no chances that the defendant's confrontation right might be abridged. While Harrington did not overrule Bruton, it certainly did for all "good" government cases. Harrington's reliance upon "overwhelming evidence" can only mean that the Bruton confrontation right is unnecessary for the apparently guilty. In Harrington's situation, a statement which could be construed to implicate was held to fall short of a confession. ${ }^{126}$

In Schneble, the petitioner's "confession"127 was more inculpatory than Harrington's, though there was some question about its reliability. ${ }^{128}$ Justice Marshall, in dissent, attempted to show that Schneble's reliance upon Harrington was misplaced because Harrington involved a codefendant's confession which was "merely cumulative" of the defendant's "confession" to having been at the scene of the crime. However unpersuasive that distinction might have been, Justice Marshall said prophetically what might just as well have been said in

\section{U.S. at 136.}

${ }^{126}$ Significantly, the majority did not consider Harrington to be a case of interlocking confessions. The statement by Harrington was a piece of circumstantial evidence no different from that provided by a witness who could testify that Harrington was around, but who could not testify to any criminal activity.

${ }^{127}$ Much of the confusion in Schneble arises from the varying views amongst the members of the Court as to the legality of the confession. Despite the limitation of the grant of certiorari to the "confrontation" question, the "confession" split on the Court has an obvious effect on the opinions.

${ }^{128}$ Schneble's first "confession" was not reliable. His second "confession" was. The second confession occurred after what the dissent characterized as "a series of bizarre acts by the police." 405 U.S. at 434 (Marshall, J., dissenting). The Florida Court found the second confession was sufficiently "attenuated" to allow its presentation to the jury. The jury's handling of the confession, and determination of whether it was voluntary, was part of the disagreement between the majority and the dissent as to the harmlessness of the offer of the codefendant's statement.
Harrington: "Unless the Court intends to emasculate Bruton, supra, or to overrule Chapman v. Califormia, supra, sub silentio, then I submit that its decision is clearly wrong." 129

Which of the precedents, Bruton or Chapman, was the target in Schneble became clear in Parker $v$. Randolph. ${ }^{130}$ Justice Rehnquist, the author of Schneble, writing for a plurality in Parker, resurrected Delli Paoli and limited Bruton to those cases in which the implicated defendant "made no extrajudicial admission of guilt." "131 The Parker plurality opinion, on confrontation grounds, was inconsistent with Bruton, relying instead on the two harmless constitutional error cases, Harrington and Schneble. Parker did to Bruton what Marshall suggested that Schneble did to Bruton, assuming Schneble to be a confrontation, not a harmless error, case. Justices Stevens, Brennan, and Marshall found Rehnquist's confrontation position untenable. Justice Powell took no part in the decision. Justice Blackmun specifically rejected Justice Rehnquist's position on Bruton but voted with him because he believed that the error was "harmless."

Justice Blackmun's use of harmless constitutional error in Parker is a classic example of an appellate procedural doctrine blocking the resolution of an important constitutional question. Had harmless constitutional error not been available to Justice Blackmun, he probably would have joined Justice Rehnquist on the merits, providing a majority for the Rehnquist position. While he rejected Rehnquist's Bruton position to make his harmless error point, ${ }^{132}$ his harmless error reasoning is difficult to distinguish from Rehnquist's Bruton position. While one might have substantial disagreement with Rehnquist's Parker position, a constitutional position ought not fail of a majority for a harmless error doctrine.

Ironically, harmless error is based on a concern for judicial economy. Had Blackmun prevailed, still another hearing and another round of appeals would have resulted, all in the interest of judicial economy. ${ }^{133}$ The right of confrontation is a consti-

${ }^{129}$ Id. at 437 (Marshall, J., dissenting).

${ }^{130} 442$ U.S. 62 (1979).

${ }^{131}$ Id. at 74 .

${ }^{132}$ Id. at 77 (Blackmun, J., concurring in part).

${ }^{133}$ Justice Blackmun, concurring in Moore v. Illinois, 434 U.S. 220, 233 (1977), begins to hint at a cure worse than the disease for the extra round of hearings. He considered the victim's in-court identification of her assailant and said: "[T]he conclusion that it was harmless seems to me to be almost inevitable." Id. at 234. While he went on to say that it was for the lower court's determination in the first instance, his apparent willing- 
tutional right. It runs consistently against the government and in favor of the defendant. It depends upon the courts for its definition. Because the harmless constitutional error doctrine exists, and was able to draw the vote of a Supreme Court Justice, the status of the right and the case, Bruton, which defined it is still in doubt. If Bruton does not state the law of confrontation, and arguably it does not, a judicial economy doctrine that does not work ought not deny us the knowledge.

When a Supreme Court Justice can frustrate the constitutional process by refusing to decide a matter on the merits in favor of a procedural doctrine invented to avoid retrials over omitted "the's," the loss is exceeded only by the danger of that same doctrine changing the constitutional process without warning. The plurality in Parker was not doing anything that the majority in Harrington and Schneble had not done under the guise of "harmless" error. The difference is that Harrington and Schneble gave poor notice that the Bruton doctrine would not apply to cases in which there was an extrajudicial statement from the defendant complaining of the confrontation failure. The harmless constitutional error doctrine is a particularly evil erosive mechanism. Assuming for a moment that methods to erode constitutional doctrines without destroying them are useful tools in the law, harmless error analysis is not one of those useful tools. Harmless error analysis does not address, nor give the opportunity to address, the merits of the doctrine being eroded. The case for gradual change in constitutional propositions by erosion is not made by resort to a doctrine that gives proponents and opponents of the constitutional proposition no opportunity to speak to the merits and courts no opportunity to signal where they are going.

Milton $v$. Wainwright ${ }^{134}$ is an example of the evil effect of the harmless constitutional error doctrine when five Justices are willing to avoid the issue as Justice Blackmun did in Parker. George Milton was indicted for murder, had a lawyer, and was in jail awaiting trial. He had made some statements that were less than fully reliable. ${ }^{135}$ The police were

ness to reach the conclusion quickly, coupled with Chief Justice Burger's procedure in Milton v. Wainwright, 407 U.S. 371, to consider harmlessness as a new matter in the Supreme Court, suggests the possibility of an increase in harmlessness decisions from the Supreme Court as a method to decide each case on its narrowest ground.

${ }^{134} 407$ U.S. 371 (1972).

${ }^{135}$ Chief Justice Burger's opinion does not mention that the "overwhelming" evidence was a set of "confessions" taken over an eighteen-day period, during which sufficiently concerned that they sent an officer into Milton's cell, posing as a prisoner. During the two days that Milton and the policeman, Langford, "roomed" together, Milton made damaging statements to the policeman which Langford related to the jury at trial. The District Court viewed Milton's habeas complaint about the statements as raising the issue presented in Massiah v. United States, ${ }^{136}$ but denied Milton any relief because Massiah had never been held to be retroactive.

Chief Justice Burger, speaking for five members of the Court in Milton, did not address the Massiah issue. ${ }^{137} \mathrm{He}$ assumed arguendo that there was error, and wrote an eight-page opinion explaining why the hypothetical error was harmless. Justice Stewart, the author of Massiah, speaking for four members of the Court, took vigorous exception to the lower court's view of Massiah, the majority's failure to consider Powell v. Alabama, ${ }^{138}$ and the Court's conclusion that the error-whatever it was-was harmless. One hardly needs to take sides on the merits of the Massiah retroactivity issue to demonstrate that the harmless error doctrine is an abomination when constitutional matters are at stake in the Supreme Court. The retroactivity of Massiah remains unanswered and the continued strength of Powell is now in doubt because five out of nine members of the Court were able to classify an unidentified error as harmless beyond a reasonable doubt. Laying aside the value of five out of nine persons finding anything true beyond a reasonable

the defendant was held incommunicado and questioned almost every day, often for hours at a time. He denied his guilt for the first ten days. See 407 U.S. at 383. Chief Justice Burger gave no consideration to the possibility that the jury may well have been unwilling to convict based upon the suspicious confessions, and gave them great weight only in view of the "harmless error"-the "voluntary" conversation with the cellmate.

${ }^{136} 377$ U.S. 201 (1964). United States v. Henry, $100 \mathrm{~S}$. Ct. 2183 (1980), decided eight years after Milton, presented almost exactly the same Massiah-relevant facts. Chief Justice Burger's majority opinion in Henry detailed an understanding of Massiah with which four Justices took issue on one basis or another. Nothing in the Chief Justice's opinion justifies, explains, or even mentions the eight years in which the Court left everybody else up in the air as to the meaning of Massiah.

${ }^{137}$ Justice Stewart, the author of Massiah, described it as a "counsel" case in Milton, while the district and circuit courts read it to be about "voluntariness." 407 U.S. at 380 (Stewart, J., dissenting). The Chief Justice's excursion into harmless constitutional error as a matter of first instance in the Supreme Court left the disagreement, along with the retroactivity question, unresolved.

${ }^{138} 287$ U.S. 45 (1932). 
doubt, substantial questions remain unanswered and new ones are raised unnecessarily. In addition, the Supreme Court spends its valuable time making a factual judgment about a long record rather than examining the law of the case, or, at least, the law of some other case. The doctrine of harmless error damages the Constitution by failing to address important issues as in Milton. It also causes a misallocation of court time which could be better spent performing tasks other than reading a long record. The harmless constitutional error doctrine in the Supreme Court is an unwarranted and dysfunctional impediment to the constitutional process.

The constitutional damage from the harmless constitutional error doctrine is not limited to the Supreme Court and its use of the doctrine to avoid constitutional judgments as in Parker, or to make constitutional judgments without real notice as in Schneble. Appellate courts, both state and federal, have occasionally been less than enthusiastic about certain constitutional decisions of the United States Supreme Court. Harmless constitutional error provides such courts an opportunity to "destroy or dilute constitutional guarantees." 139 The doctrine is unmatched as a tool for the secret theft of constitutional rights. A finding that a constitutional error is harmless is almost beyond question or review. While there are some fact circumstances and trial situations so obvious that it is incredible that any appellate judge would make a harmless error finding, ${ }^{140}$ most such findings are based upon long and relatively inaccessible records. Further, the majority opinion will generally reflect those portions of the record which support the "harmless" determination. If there is no dissent on the

${ }^{139}$ Justice Harlan's Chapman dissent recognized the danger and reserved the eventuality of state court dilution of federal constitutional rights as a basis for his concurrence with a decision which would prohibit the activity by imposition of a federal standard. 386 U.S. at 50.

${ }^{140}$ A rare example of a harmless constitutional error decision which is so preposterous on its face that no particular resort to a record is required is found in Allison v. Gray, 603 F.2d 633 (7th Cir. 1979). The error was a failure to allow the defendant to present his alibi evidence. The Wisconsin Supreme Court and the federal district court apparently believed that the government's case was so overwhelming that there was no need for a jury to listen to and believe the defendant's case. Short of this kind of a case, in which the court finds the failure of the government to allow a trial to be harmless, harmlessness is not easily seen by the reviewer without benefit of a full record. law, there is not likely to be a dissent on the factseven if a judge might have some question about the facts. ${ }^{141}$

If a state or federal appellate court chooses to use the harmless constitutional error as a tool to emasculate a constitutional right through a consistent finding of harmlessness in a series of cases, it is likely to succeed without question. Although prosecutors who handle cases within a jurisdiction may watch closely to see which area of error is becoming "harmless," 142 commentators, the people most likely to be concerned with a pattern of dilution, are unlikely to be alerted, given the ląck of legal mistake with which to quarrel. A given defendant may press through the habeas corpus maze to appeal a state determination of harmlessness or appeal to the Supreme Court from a circuit court harmlessness decision, but the likelihood of a successful appeal of a harmlessness affirmance is slim. Given the number of harmless constitutional error decisions, and the difficulty in finding reversals of those decisions by a higher appellate court, the potential of the harmless constitutional error doctrine for unmaking law has not gone unnoticed by appellate tribunals. ${ }^{143}$ While there may be some other explanation for the marked increase in the use of harmless constitutional error, avoidance of

${ }^{141}$ Milton v. Wainwright, 407 U.S. 371, exemplifies the situation where there is a quarrel about the factual finding of harmlessness which would not likely have occurred but for the legal dispute. Even in Harrington and Schneble, the dispute on the facts is only in furtherance of the complaint about the test the Court is adopting.

142 The problem of prosecutorial deterrence is considered at text accompanying notes 154-159 infra. Justice Cameron of the Arizona Supreme Court has observed that the result of consistent signals to prosecutors is prosecutorial reception of the signals: "[I]f a particular error is declared to be harmless a sufficient number of times, then the cumulative effect of such holdings will be that both the prosecution and the trial judge will tend to ignore the error and commit it again." Cameron \& Duke, When Harmless Error Isn't Harmless, 1971 Law \& Soc. ORD. $23,42$.

${ }^{143}$ Whether the absence or presence of second level reversals of harmless determinations would be the more unhappy circumstance is unclear. Given the large number of harmless cases, it seems fair to conclude that the small number of second level reversals is directly related to the difficulty of review of a factual judgment. On the other hand, a significant number of second level reversals on harmless error would be sorry proof that lower appellate courts were, indeed, hiding behind harmless error as a means to dilute constitutional rights. The other possibility, that there is an incredible increase in the number of trial mistakes that do not matter in fact, has little to support it in logic or evidence. 
constitutional responsibility is not without precedent. $^{144}$

Harmless constitutional error presents special problems for trial courts and prosecutors that are not a concern when the harmless error is "common." Because harmless constitutional error always operates in favor of the government and against the defendant, the doctrine puts unique pressure on a conscientious trial judge or prosecutor to ignore a citizen's acknowledged constitutional rights based upon the "no harm-no foul" theory. ${ }^{145}$

Trial courts make the first, and often most influential, ${ }^{146}$ decision concerning the constitutional rights of the defendant. It is the trial court, and particularly the state trial court ${ }^{147}$ where the cost

${ }^{144}$ Justice Powell, concurring in Argersinger v. Hamlin, 407 U.S. 25, 65 (1972), had no hesitancy in ascribing "the failure of many state courts to live up to their responsibilities in determining on a case-by-case basis whether counsel should be appointed" as a motive behind the landmark decision in Gideon v. Wainwright, 372 U.S. 335 (1963).

${ }^{245}$ Although demonstrating the effect of any decisionmaker's benign neglect is difficult, the art form from which the phrase is taken, professional basketball, presents an interesting analogy. Before the "no harm-no foul" type interpretations of the rules by modern referees, basketball was considered a kind of sporting dance inappropriate (in those days) for "men." Anyone watching the modern no harm-no foul game can attest that a portion of that contact sport resembles a war zone. It is difficult for one trained in the law to assume that prosecutors and judges would not be at least as quick as basketball centers and referees to adjust to this kind of development.

${ }^{146}$ The first judgment is the standard against which other possibilities are considered. The trial court's judgment about both the facts and the law often influences decisions three or four appellate layers later. See, e.g., Rhode Island v. Innis, 100 S. Ct. 1682, 1690 n.9 (1980) (quoting trial judge), where the trial judge's statement that it was "entirely understandable that [the officers in the police vehicle] would voice their concern" made it all the way to a United States Supreme Court opinion and served as a part of the foundation for the proposition that there was no "interrogation." See also Note, Fifth Amendment-The Meaning of Interrogation Under Miranda, $71 \mathrm{~J}$. CRIM. L. \& C. 466 (1980).

${ }^{147}$ Justıce Harlan consistently maintained that the circumstances of the states were very different from the circumstances of the federal government. His argument in Chapman, that federalism should be the first constitutional principle, persuaded no one on the Court. Regardless of the impotence of the argument for law, the fact is that there is a huge difference between the circumstances and relationships of a federal trial court and a state trial court. The discussion which follows assumes a trial in a state trial court, the forum in which the vast majority of criminal litigation takes place. of the exclusion of evidence, for instance, is most immediately appreciated. Justice Frankfurter's admonition that "the safeguards of liberty have frequently been forged in controversies involving not very nice people, ${ }^{\prime 148}$ is rarely lost on a trial judge, who is usually looking over the bench at the "not very nice" person. Unfortunately, there is no method for documenting the effect of the harmless constitutiónal error doctrine on trial courts. Aside from the fact that most trial court opinions go unpublished, the issue of "harmlessness" is never officially raised at the initial confrontation over the loss of a constitutional guarantee.

Some observations about the operation of trial courts and their place in the community might help fill the void left by the failure of formal opinions. Acknowledging the danger in anecdotal proof, I doubt that I am the only lawyer in the land who, when citing a precedent for error, has had the trial court review the precedent and say: "Counsel, I agree that the court held that to be error. But they said that it was harmless, and I think that this case is virtually the same as your precedent." 149 Predictably, the trial court focuses on the precedent's harmlessness determination rather than on the determination that there was indeed an error.

Most constitutional matters arise in special pretrial hearings under the glare of some publicity. ${ }^{150}$ Significantly, appellate courts decide such matters far away and after the heat is off. Trial judges live in, socialize with, and are, by design, subject to the influence of the community. ${ }^{151}$ What ought such a

${ }^{148}$ United States v. Rabinowitz, 339 U.S. 56, 69 (1950) (Frankfurter, J., dissenting), overnuled, Chimel v. California, 395 U.S. 752 (1968).

${ }^{149}$ This composite response reflects some experience in response from trial judges commenting upon precedent which had good news and bad. The good news was the error, the bad news was that it was harmless. While a careful advocate would find precedents which showed only the error, the opportunity for that selection decreased rapidly after Chapman as more and more cases found both error and harmlessness.

${ }^{150}$ Gannett Co. v. DePasquale, 443 U.S. 368 (1979), demonstrates that the pretrial hearing is often of as much public interest and concern as the trial. The trial court's decision to close the hearing may reflect something more than a concern for an impartial jury. The Supreme Court's willingness to allow the closure may evidence an unstated understanding of the pretrial pressures on judicial decisionmakers. See also Richmond Newspapers, Inc. v. Virginia, 100 S. Ct. 2814 (1980) (trial must be open to the press); Note, Constitutional Right of Access to Criminal Trials, 71 J. CRIM. L. \& C. 547 (1980).

${ }^{151}$ Even in those "enlightened" jurisdictions which 
judge do if a defendant charged with murder, and against whom there is overwhelming evidence of guilt, makes a motion to suppress evidence because of a violation of the Constitution? Justice Cardozo's reminder ${ }^{152}$ of the high price society pays for a decision to exclude evidence is best understood by a trial judge. To that problem for the trial court, add the proposition that appellate courts may find constitutional error to be "harmless" and that in a relatively similar case the highest court of the state has once done just that. The trial court can read the highest court of the state to be holding that the error in question will always be harmless. ${ }^{153}$ It may read the court to be signaling a change in the law, and it may be correct. Last, and for constitutional protection, probably worst, the trial court may be correct in its view that the instant case and the precedent are factually so similar that the same harmless constitutional error determination would probably obtain upon review. The result will be the same, regardless of which view the trial court takes. Either because the error is always harmless, or the law is changing, or because it can accurately predict that this particular error in this context will be harmless, the trial court will consciously commit constitutional error, safe in the "instruction" to do so from the state's highest court. The result is a doctrine which, in the guise of judicial economy, almost requires the trial court to initially ignore the enforcement of constitutional rights. Significantly, the hypothesized activity does not depend

have adopted plans for judicial selection other than the election contest, some form of community veto exists upon the performance of judicial trial function. Most jurisdictions maintain the election of trial judges, and while the upset of a sitting judge is rare, it does happen. More importantly, the trial judge, as opposed to the appellate judge, suffers or enjoys all of the personal concerns for acceptance within the community of which the judge is not only an integral, but an important and visible part.

${ }^{152}$ See note 116 \& accompanying text supra.

${ }^{153}$ At least one court has determined that a constitutional error can never be harmful. In State ex rel. McMannis v. Mohn, 254 S.E.2d 805 (W. Va. 1979), the West Virginia Supreme Court of Appeals held that violation of the principle in Estelle v. Williams, 425 U.S. 501 (1976) (defendants may not be forced to attend trial in prison garb), was harmless constitutional error when the defendant was on trial for a crime committed while in prison, and when the defense failed to raise its objection until after calling its first witness. Whether the decision might have been justifiable under a due process theory, or whether Estelle is distinguishable (the court's opinion) was beside the point. The West Virginia Court chose to create the anomaly that certain activity was always error and always harmless. upon any ulterior motive upon the part of the trial court. Quite the contrary is true. A respectable argument can be made that when a local trial judge is faced with the possibility of turning a "murderer" loose for the violation of a constitutional right which an appellate court has said in the same context led to a harmless constitutional error, the judge should err in favor of community safety. A "correct" result of guilty, given the certainty, likelihood, or possibility that the appellate court will say that the trial court's error was harmless is more appropriate than any other result. It is also easier, and in this situation "easier" is not necessarily pejorative.

The result of the harmless constitutional error doctrine at the trial court level is to encourage the diminution of rights against the government for all individuals against whom the state has an overwhelming case. ${ }^{154}$ Harmless constitutional error then becomes the presumption rather than the exception. The fault is not with the trial court but with the concept that the abrogation of a constitutional right that runs consistently against the government can be harmless.

As difficult as it is to isolate the effect of the harmless constitutional error on trial courts, it is even more obscure with prosecutors. There is, nevertheless, the nagging suspicion that the major denial of constitutional guarantees resulting from the harmless constitutional error doctrine relates to its effect upon prosecutors. Again, one need not posit the evil-minded prosecutor to demonstrate that harmless constitutional error steals significant rights by its effect upon the prosecuting authority. Prosecutors, as with all lawyers, are trained to represent their client to the limit of the law. The profession considers it unethical and unthinkable for the advocate to cross over the line, and malpractice not to approach that line as closely as possible in pursuit of the client's just cause. The prosecutor's duty to "justice,"155 may raise some

154 The difference between the "effect of the evidence" test and the "overwhelming evidence" test may be of significance in this situation. At least with the former test, the trial court is not encouraged to prejudge the strength of the prosecution's case and make an error/no error decision based upon that judicial prejudgment of guilt.

${ }^{155}$ A sense of uneasiness pervades the common suggestion that prosecutor/advocates are somehow different from other advocates and can psychologically suffer pulling selected punches in the interest of justice. See, e.g., Standards Relating to the Prosecution and the Defense Function, ABA Standards Relating to the Administration of CRiminal Justice, Standard 3-1.1 (approved draft, 1979) 
doubt about how he should respond to a constitutional violation, but the prosecutor's instincts as a lawyer combined with the harmless constitutional error doctrine, demand that the prosecutor abdicate any role as a positive force for the maintenance of constitutional guarantees. ${ }^{156}$

When constitutional rights are at issue in the courts, prosecutors have a consistent position. Either as the result of the facts they are given or as a matter of government or personal policy, the prosecutor is arguing in court that an alleged violation of a constitutional right is not a violation, or if it is, should not vitiate a good case. ${ }^{157}$ The same is not necessarily true when nonconstitutional rules are at stake. The result is that the prosecutor contributes to the erosion of doctrines in the courts by maintaining a consistent position with respect to the harmlessness of constitutional error. To the extent that any litigant can find the opportunity or mechanism to argue harmlessness to the appellate tribunal, it is the prosecutor. Furthermore, since the prosecutor is a consistent litigant against opponents with one-case or one-issue interests, the prosecutor can, over a series of cases, maintain a position which is beyond the power of any single opponent to effectively confront.

The harmless constitutional error doctrine even affects the prosecutor in the investigation and trial stages. When an advocate is faced with a trial burden of proof beyond a reasonable doubt, he has the inclination and opportunity to watch the cases to see which errors are consistently harmless and which are not. Where the trial task and individual

("The duty of the prosecutor is to seek justice, not merely to convict."). It is difficult to include under that umbrella the suggestion that a prosecutor is somehow bound not to take advantage of evidence which that prosecutor knows will be considered "harmless" even if it might be technical constitutional error.

${ }^{156}$ The prosecutor's potential as a force for the preservation of constitutional values is twofold. While the prosecutor has an obvious role in refusing to present evidence which will result in reversible error, in many instances the prosecutor also can be effective in directing law enforcement policies and activities.

${ }^{157}$ Any suggestion that the office of prosecutor presents a unique circumstance in which the office holder has an obligation to suppress constitutionally infirm evidence or at least refuse to argue its harmlessness is based on a misunderstanding of the adversary system in fact, and probably in theory. See, e.g., Milton v. Wainwright, 407 U.S. 371 , in which at least one prosecutor argued "harmlessness first" all the way to the Supreme Court. It is the prosecutor's continuing stake in the merits and ability to profit from consistent "harmless" decisions in lieu of a victory on the merits that helps to make the doctrine of harmless constitutional error particularly pernicious. temperament demand every available weapon, the doctrine presents a situation in which only the most foolish of prosecutors would avoid the risk of using the error. Every time an error is declared harmless in a particular situation, it diminishes the risk to the prosecutor in the use of the evidence or the technique. ${ }^{158}$ The lessening of the risk is added into a formula which favors risk-taking based upon the doctrine alone. In a sense, the doctrine encourages the prosecutor to use the evidence or the technique in every case. Initially, there are three

${ }^{158}$ Situations in which prosecutorial conduct may be influenced by "harmless" decisions are difficult to identify. It may be reckless to ascribe motive from a consistent line of cases, but a series of decisions in the Minnesota Supreme Court leaves the distinct impression that prosecutors respond to what they read.

In State v. Jones, 277 Minn. 174, 152 N.W.2d 67 (1967), the Minnesota Supreme Court reversed a conviction because of prosecutorial misconduct. Among other items the prosecutor argued to the jury the failure of a witness to answer certain questions. Id. at 183,152 N.W.2d at 74. The reversal was, however, the result of multiple sins. State v. Russell, 282 Minn. 223, 164 N.W.2d 65, cert. denied, 396 U.S. 850 (1969), concerned an improper argument wherein the prosecution alluded to the defendant's failure to call witnesses. The court said, "we do not approve," but refused to reverse because the remainder of the evidence was so overwhelming. Id. at 228,164 N.W.2d at 68 . In each of the next seven years, the court had at least one occasion to tell prosecutors that it was error to comment upon a defendant's failure to call witnesses, and in no instance did it reverse for that reason. Most of the cases come from the same prosecutor's office. All but one came from the three major metropolitan prosecutors' offices. While it cannot be shown that the continued comment on the failure to call witnesses is a direct result of the failure of the court to reverse, the court kept affirming and the prosecutors kept commenting. See State v. Spencer, 311 Minn. 222, 248 N.W.2d 915 (1976) (defendant's testimony); State v. Redd, 310 Minn. 145, 245 N.W.2d 257 (1976); State v. Fields, 306 Minn. 521, 237 N.W.2d 634 (1976); State v. Meadows, 303 Minn. 76, 226 N.W.2d 303 (1975); State v. Caron, 300 Minn. 123, 218 N.W.2d 197 (1974); State v. White, 295 Minn. 217, 203 N.W.2d 852 (1973); State v. Bell, 294 Minn. 189, 199 N.W.2d 169 (1972).

Two related lines of cases show the same tendency for "repeat business," or prosecutorial conduct which is "disapproved" but for which the Court continuously refuses to reverse. See generally State v. Shupe, 293 Minn. 395, 196 N.W.2d 127 (1972). Shupe disapproved the prosecutor's implication to the jury that he would have provided more evidence but for some circumstance. In at least three subsequent cases the same comment was disapproved without reversal. In State v. Thomas, $307 \mathrm{Minn}$. 229, 239 N.W.2d 455 (1976), the court acknowledged that its admonition to prosecutors in a 1933 case regarding the misrepresentation of the presumption of innocence was going unheeded. It did not reverse but said it would henceforth. Eight cases later it had not reversed and gave no indication that it ever would. 
possibilities: (1) the evidence or technique does not involve any error, (2) if the evidence or technique involves error, it will be harmless, and (3) the evidence or technique involves error that will cause a reversal because the remainder of the evidence is not "overwhelming." What should the intelligent and conscientious risk assessor do? The first two possibilities present no question. If there is no error there is no problem, and if the error is harmless the only problem is the time and expense of an appeal. The result is the same: a legal conviction. Convictions which are legal are, after all, what the society pays the prosecutor to obtain. The third choice is the problem. The court has defined a doctrine of harmless constitutional error which says to a prosecutor that if the case is not overwhelming any error will cause a reversal, and if it is overwhelming, no worry. The prosecutor then looks at the case and determines that it is not very strong. Use of the evidence or technique has two chances of success-no error and harmless-and one chance of failure. By the Court's definition of "harmless," that one chance of failure demands that the evidence or technique be crucial to the prosecutor's case. The prosecutor has no advocate's choice which mitigates in favor of not using the evidence or technique. Even if the prosecutor believes the case is strong, the likelihood is that the evidence or technique will be used. The odds are still two-toone. Further, the advocate's predilection to cover every base is reinforced by the doctrine's admonition: if the evidence or technique is not needed by the advocate it is not likely to cause a reversal. ${ }^{159}$

The effect of the rule upon the government's advocate is particularly significant. Prosecutors are among the most deterrable of groups. If any of the Supreme Court decisions of the last quarter century have a deterrent effect, prosecutors are the prime group to respond. Not only are they affected directly by reversals, they are sufficiently trained and have sufficient time to fully appreciate the prece-

${ }^{159}$ Harrington v. California, 395 U.S. 250 (1969), was, according to Justice Douglas, just such a case. His view, represented by Justice Marshall's dissent in Schneble v. Florida, 405 U.S. at 433, was that the Harrington evidence was merely cumulative. The confession in Milton v. Wainwright, 407 U.S. 371, seems another example of just one more piece of evidence which a prosecutor placed upon an already very large pile. The best proof that prosecutors are likely to use all they have, even if they don't need it, is the number of times that appellate courts, by finding harmless constitutional error, have said that the prosecutor used evidence that wasn't needed. dent. ${ }^{160}$ The harmless possibility, then, tempts a group that might in its own self interest be a significant force for preserving the constitutional right and, in addition, influence law enforcement to do the same.

\section{No RHYME NoR REASON}

The prosecutor's position with respect to a constitutional right which may lead to error exemplifies the last, and most ironic, problem with the harmless constitutional error doctrine. Harmless error exists only as a means of judicial economy, and harmless constitutional error does not even economize judicial time or activity. ${ }^{161}$ The judicial economy theory assumes that a rule which allows reversal only when the error is substantial will diminish the number of retrials and thus cut judicial time and speed matters to conclusion. ${ }^{162}$

The harmless constitutional error doctrine, as it affects the prosecutor, contributes to court congestion. Although quantification is impossible, the doctrine clearly causes some diminution in the prosecutor's concern that abrogation of a constitutional right will cause a reversal. Consequently, the prosecutor will use the evidence or technique in a number of cases which, without the doctrine, he would not. Each such case represents one trial which, without the doctrine, might not have taken place. In the event of a conviction, an appeal is almost guaranteed because there is an obvious constitutional error. If the prosecutor was right and the error was, indeed, harmless, the net effect of the use of the evidence under the shield of the doctrine is one more appeal. If, on the other hand, the prosecutor's guess was wrong, and the error was harmful, there is one more appeal and one more trial, where, without the doctrine there might

${ }^{160}$ One of the major complaints about the extension of the exclusionary rule has been that policemen have neither the training to understand it nor do they find themselves in situations in which their action can be affected by an arcane judicial precedent. See Bivens v. Six Unknown Named Agents, 403 U.S. 388 (1971). Prosecutors, on the other hand, are the specific group at which exclusionary deterrence might properly be aimed.

${ }^{161}$ Empirical proof of economy is virtually impossible. Professor Saltzburg, supra note 4, at 1032 n.158, presents an interesting view of the de minimus effect of harmless error in criminal trials in the federal system. Nothing in either the cases or the literature presents a detailed argument for the proposition that harmless constitutional error presents the same judicial economy claimed for harmless common error.

${ }^{162}$ See generally State v. Link, 289 N.W.2d 102 (Minn. 1979). 
have been no trial in the first instance. There is no instance in which the harmless constitutional error doctrine encourages prosecutors not to file cases which would not otherwise be tried, and many chances for the filing of additional cases because the doctrine exists.

The effect of the doctrine on trial courts also contributes to court congestion and works against the rationale that supposedly supports the doctrine. To the extent that the doctrine encourages a trial judge to allow evidence even though it is likely error to do so, the doctrine destroys another opportunity to diminish litigation. In some cases, if the trial court suppressed the evidence, the prosecutor would decline to proceed. To whatever extent the doctrine discourages the suppression, it increases the number of trials. In addition, each time the failure to suppress involves a constitutional error, it almost guarantees an appeal and another full record hearing in the appellate court before the litigation is laid to rest because the error was harmless.

Moreover, it is not clear that the harmless constitutional error doctrine contributes to judicial economy at the appellate level. Undoubtedly, some cases are not retried because the court found error but found it harmless. How large that number might be is as difficult to ascertain as some of the other possibilities which have been discussed. It is, however, fair to observe that in order for the error to be harmless the case against the appellant must be "overwhelming" without the error. If the government's case is that good-and the defendant has already seen it succeed once-the chance for a plea after the appeal is enhanced. If the court finds the error and does not have the harmless error doctrine to fall back on, the government is more interested in the defendant's plea than it was before trial. Whatever the number of retrials avoided by the harmless constitutional error doctrine, it is diminished by the increased likelihood of a plea if the doctrine is abandoned.

Importantly, when the error in question is constitutional rather than common, any resuliant trial economy is offset by the certainty of the increase in appeals. While a defense attorney may persuade a defendant that a truly insignificant common error is not an adequate foundation for an appeal, that same result is not likely when both the lawyer and the defendant know the Constitution is implicated. The net economy effect of the doctrine upon appellate courts and trial courts cannot be left without noting that the issue of harmlessness raises yet one more determination from which the defendant might take yet one more appeal. For every trial that the harmless determination might save, there is an appeal to be spent. ${ }^{163}$

A last unique aspect to constitutional error differentiates it from common error when the judicial economy argument is made for a harmless error doctrine. The major reason for including the criminal trial within the original harmless error rule was the prevailing practice among defense attorneys of putting error in the record as a hedge against a guilty verdict. ${ }^{164}$ The effect of that system, which provided the only litigant with an interest in never reaching a decision a technique to forever forestall the reaching of a decision, was to never reach a decision. Constitutional error, however, is beyond the control of the defense lawyer for the most part. It is difficult to place a bad search, a bad statement, a bad lineup, the failure of counsel, or other government error into the record. The need for a harmless error rule to avoid retrials caused by defendants does not exist for constitutional error.

\section{Conclusion}

The harmless constitutional error doctrine shares neither history nor logic with the harmless error doctrine from which it was wrenched in Chapman. It offers neither logic nor method for finding proof for the proposition that judicial economy results from the operation of the doctrine. Indeed, the doctrine arguably contributes to the amount of judicial time spent on criminal cases. Unfortunately, the doctrine enjoys great popularity with appellate courts as a mechanism for reducing the strict enforcement of criminal constitutional procedure rules.

The effect of the doctrine upon precedents defining constitutional criminal procedure-their creation, maintenance, and change-is devastating. As to constitutional rights there should be no harmless error. ${ }^{165}$ The Court should adopt a rule of auto-

${ }^{163}$ Constitutional error presents the added possibility of federal habeas corpus. But see Stone v. Powell, 428 U.S. 465 (1976) (ending federal habeas corpus in fourth amendment cases). Insofar as many jurisdictions have two levels of appellate courts, and the federal habeas procédure might involve three levels of review, a strong argument can be made that it takes more time going up the ladder to resolve the harmlessness issue than it would take to go back down and try the case without the error.

${ }^{164}$ See note 14 supra.

${ }^{165}$ Chief Justice Burger concedes that the judicial economy realized by saving one jury trial is outweighed by 
matic reversal, fulfill its function with respect to the Constitution, and make its judgments in full light of the undiluted effect of the rules it makes.

A terrible symbolic price is paid for maintenance of a harmless constitutional error rule. There is a visceral, if nonlegal distaste for the proposition that an individual's loss of a constitutional guarantee, protected only by the courts, can somehow be "harmless." An improper search of a home should not be equated with a state's omission of the word "the" from the defendant's charging papers. Law-

the interest in safeguarding the rights of the individual defendant. Writing for a unanimous court in Standefer v. United States, 100 S. Ct. 1999 (1980), the Chief Justice held that the civil doctrine of nonmutual estoppel would not be applied in criminal cases because the "important federal interest in the enforcement of the criminal law" outweighed the "economy concerns that undergird the estoppel doctrine." Id. at 2008. In distinguishing the criminal from the civil, he concluded with an approving quotation of the Court of Appeals rationale for that distinction:

"The purpose of a criminal court is not to provide a forum for the ascertainment of private rights. Rather yers should pause at the proposition that government can violate a basic restriction upon itself and, through a court, tell the individual who was the beneficiary of the restriction: "no harm-no foul."166

There is something disquieting about the admission that constitutional rights are so often abrogated that we need a separate doctrine to excuse some of them so that our decisionmaking system will not break down. Finally, there is some shame in trying to explain how the loss of a constitutional guarantee is harmless beyond a reasonable doubtfive-to-four.

it is to vindicate the public interest in the enforcement of the criminal law while at the same time safeguarding the rights of the individual defendant. The public interest in the accuracy and justice of criminal results is greater than the concern for judicial economy...."

Id. (emphasis added) The judicial economy concern in both the nonmutual estoppel situation and in the harmless constitutional error case is exactly the same: one jury trial.

166 "No man ought certainly to be a judge in his own cause, or in any cause in respect to which he has the least interest or bias." The Federalist No. 80 (A. Hamilton). 